\title{
Efficient Epoxidation of Alkenes with Hydrogen Peroxide and Electrochemical Behavior in Water Over Heteropolymolybdate/ Silica Nanocomposite
}

\author{
Hossein Salavati, Abbas Teimouri \\ Department of Chemistry, Payame Noor University (PNU), 19395-3697, Tehran, I.R. IRAN \\ *E-mail: hosseinsalavati@ pnu.ac.ir
}

doi: $10.20964 / 2017.08 .20$

Received: 14 February 2017 / Accepted: 25 May 2017 / Published: 12 July 2017

\begin{abstract}
A $\left(\mathrm{PVMo} / \mathrm{SiO}_{2}\right)$ nanocomposite catalyst was synthesized by immobilization of vanadium substituted heteropolymolybdate (PVMo) in mesoporous silica. The nanocomposite catalyst was characterized by different physico-chemical techniques such as elemental analysis, FT-IR, UV-Vis, XRD, SEM, TEM, BET and cyclic voltammetry. The $\mathrm{PVMo} / \mathrm{SiO}_{2}$ nanocomposite catalyst was used for alkene epoxidation with $\mathrm{H}_{2} \mathrm{O}_{2}$ as oxidant, under agitation with magnetic stirring and ultrasonic irradiation. Effect of reaction parameters such as amount of oxidant and catalyst, reaction temperature and intensity of ultrasonic irradiation were studied. This catalyst can be recovered several times with little failure of its activity. The obtained consequences explained that the catalytic activity of the nanocomposite $\left(\mathrm{PVMo} / \mathrm{SiO}_{2}\right)$ was upper than that of chaste heteropolymolybdate..
\end{abstract}

Keywords: Heteropolyanion, nanocomposite, epoxidation, Ultrasonic irradiation.

\section{$\underline{\text { FULL TEXT }}$}

(C) 2017 The Authors. Published by ESG (www.electrochemsci.org). This article is an open access article distributed under the terms and conditions of the Creative Commons Attribution license (http://creativecommons.org/licenses/by/4.0/). 